\title{
DETERMINATION OF SOIL ENDANGERMENT BY WIND EROSION WITH CONSIDERATION OF LEGISLATIVE CHANGES IN ACCEPTABLE SOIL LOSS
}

\author{
JOZEF STREĎANSKÝ, LENKA LACKÓOVÁ, ANNA STREĎANSKÁ, VIKTOR VARGA*
}

Department of Landscape Planning and Ground Design, Faculty of Horticulture and Landscape Engineering, Slovak University of Agriculture, Hospodárska 7, 94976 Nitra, Slovak Republic; e-mail: viki.varg@gmail.com

*Author for correspondence

\begin{abstract}
Stred’anský J., Lackóová L., Stred’anská A., Varga V.: Determination of soil endangerment by wind erosion with consideration of legislative changes in acceptable soil loss. Ekológia (Bratislava), Vol. 34, No. 1, p. 1-6, 2015.

Value tightening of acceptable soil loss by wind erosion in amendment to the Act No. 220/2004 on Protection and Use of Agricultural Land in the Slovak Republic from 1st of April 2013 is necessary to reconsider wind erosion intensity in agricultural territories. The paper presents results of wind erosion intensity calculation by using Wind Erosion Equation (WEQ) that is recommended by Act No. 220/2004. As observed we choose cadastral area Močenok territory and had determined and compared changes in levels of soil endangerment of arable land by wind and spatial delamination of wind erosion in specific territory of Močenok. According to WEQ calculation, we determined that soil loss from 3778.85 ha arable land is 1220.52 ha, which is highly endangerment by wind erosion. By defining levels of soil erosion endangerment (LSEE), we found out that area in 3rd class of endangerment rose from $1.48 \%$ to $43.37 \%$ after changing acceptable soil from 40 to $15 \mathrm{t} \mathrm{ha}^{-1}$ year $^{-1}$. Results enable us to specify priority areas where to implement erosion control measures in according to sustainable use and protection of arable land in model area.
\end{abstract}

Key words: wind erosion, change of acceptable value of soil loss, levels of soil loss endangerment, wind erosion equation.

\section{Introduction}

Fundament of wind erosion (aeolian) consists of soil surface degradation by mechanical force of wind (abrasion), transport and transfer of soil particles (aggregates) by wind and sedimentation on other places (accumulation). According to FAO wind erosion is one of the six main processes of soil degradation (Bujnovský, 2007). Approximately 150000 ha of soil are threatened by wind erosion in Slovakia which represents 6.2\% of whole arable land (Kobza et al., 2010; Stredanský, Grešová, 2012). Wind erosion occurs largely in Záhorie, parts of Danubian lowland and in small locations of the south of middle and eastern Slovakia (Vilček, 2007; Bielek, 2008).

According to Stredanský et al. (2006) intensity and process of wind erosion is possible to determine similar to water erosion by many methods. Deflametric method can be used for field measures 
(Stredanský, Stred’anská, 2001). Measurements like this has been done by Švehlík (1989), Fryrear et al. (2001), Stredanský et al. (2006), Grešová, Stredanský (2011), Urban (2012), and Lackóová et al. (2013). Aerodynamic tunnels were used for determination of soil erodibility in laboratory conditions; this method was used by Pasák (1970), Stredanský (1993) and others. The easiest method to determine approximate soil endangerment by wind is to use bonit soil-ecological unites (BPEJ), this method is used by STN 744501 (Antal et al., 2000). Measurements in field conditions are circuitous and challenging. That is the reason why various mathematical equations and models for wind erosion intensity calculation been derived. For example, equation according to Pasák et al. (1984), Janeček et al. (2005) and others, same as mathematical models used in these days: Wind Erosion Equation (WEQ) and Revised Wind Erosion Equation (RWEQ). WEQ has been published by Woodruff and Siddoway (1965) and it is been derived by Vrána (1977) for Czechoslovakia climate and soil conditions. While soil erodibility is the main factor in WEQ model, RWEQ is taking wind into consideration more than soil properties (Fryrear et al., 2001). According to Varga and Stredanský (2013) model, WEQ is able to be applied in our conditions but model RWEQ needs to be studied and individual values for factors need to be determine. For erosion control measures, it is necessary to determine so-called acceptable (tolerated, limit) value of soil intensity (erosion). While according to Act No. 220/2004 on Protection and Use of Agricultural Land in the Slovak Republic were acceptable soil loss determine to $40 \mathrm{tha}^{-1} \mathrm{year}^{-1}$, at present it is in amendment of this Act No. 220/2004 (according to Decree of the Ministry of Agriculture and Rural Development No. 59/2013) from 1st April 2013 acceptable value $15 \mathrm{tha}^{-1}$ year $^{-1}$.

In our study, we have evaluated consequences of this amendment that is reflected in changes of plot area in agricultural land, where it is necessary to arrange erosion control measures against wind erosion processes on specific territory of cadastral area Močenok.

\section{Material and methods}

For the survey to determine wind erosion endangerment, we have chosen cadastral area Močenok in county Šala. Cadastral area is situated in Danubian Lowland in southwest part of Nitra heights. Area elevation is 115-200 m above sea level range. In general, it is flat terrain with undulate characteristics (Miklós et al., 2002).

Cadastral area is in region with warm climate, warm zone, dry, with mild winter. In long term (1951-2000) average annual temperature was $9.7^{\circ} \mathrm{C}$, average temperature in July is around $19.5^{\circ} \mathrm{C}$, in growing season is $16.5^{\circ} \mathrm{C}$. Average annual rainfall is $556.3 \mathrm{~mm}$. There is a maximum of 40 days annual with snow cover. North-west wind direction is typical for this region with annual average wind speed $4.2 \mathrm{~m} \mathrm{~s}^{-1}$ (Špánik et al., 2004).

Most widespread soil type in cadastral area Močenok are various types of chernozem. They bind mostly to northern part of area with undulating terrain on loess soil. Southern parts of area were affected by alluvian modelation of terrain, mostly chernozem with changing moisture regime. The largest representation from soil texture is loam soil (moderate heavy weight) - 79.35\%, sandy loam soil (moderate light weight) - 17.56\%, sand and loamy sand soil (light weight soil) - 1.93\%, clay loam soil (heavy weight soil) $-1.14 \%$ and very heavy weight soil $-0.02 \%$ from agriculture land (Urban, 2012).

Structure of individual plots is: agricultural land - 4078.90 ha, from that arable land - 3778.85 ha, vineyard - 36.71 ha, gardens - 99.69 ha, orchards - 3.03 ha, permanent grassland - $160.62 \mathrm{ha}$. Area of non-agricultural land is 789.09 ha and from that forest land -269.10 ha, water surface -43.81 ha, built-up area -415.79 ha and other land -31.38 ha.

According to the legislation in Slovak Republic (Decree of the Ministry of Agriculture and Rural Development No. 59/2013) recommended equation to calculate real values of wind erosion is Wind Erosion Equation in this form:

$\mathrm{E}=f(\mathrm{I} \mathrm{KCL} \mathrm{V})$

where: $\quad$ E - Calculated average annual soil loss in hectares per year,

$f$ - Indicates relations that are not in straight mathematical calculation, 
I - Soil erodibility factor,

$\mathrm{K}$ - Soil ridge roughness factor,

C - Climate factor,

L - Width of field factor,

$\mathrm{V}$ - Vegetative cover factor.

Wind erosion equation is not simple result parameters of erodibility, but it is a group of complex relations these parameters that influence erosion (Stredanský, Grešová, 2012).

I - Factor

Soil erodibility factor values have been derived on basis of bonit-soil ecological units and potential endangerment of wind erosion. In area of interest I factor has values 138, 213 and 331 for respective areas of bonite-soil ecological unites. Slovak technical norm STN 754501 methodology been used (Antal et al., 2000).

K - Factor

Soil ridge roughness factor has been determined by influence of ridges and furrows created by tillage technology. In most calculations $\mathrm{K}$ factor is disregarded, so value 1 is used whole cadastral area.

C - Factor

Climate factor values have been calculated for last 30 years on basis of Vrána (1977), USDA (1988) and USDA (2002) methodology. Values calculated by Vrána (1977) methodology are significantly different from USDA methodologies. Correlation coefficient in comparing USDA methodologies has been 0.987 , what state for strong statistic dependency among compared parameters. In case of comparison Vrána (1977) and USDA (2002) methodology correlation coefficient has been 0.585. Based on these facts, we concluded that USDA (2002) and USDA (1988) methodology is correct for our conditions. If equation for this factor according to USDA (1988) methodology is used, it is not necessary to recalculate units from International System of Units to Anglo-American unit system. Climate factor value according to these calculations is 10.38 for area of interest.

\section{L - Factor}

Width of field factor has been calculated in Arc GIS 10.0 environment by Flow Length tool. Protected length of erosion surface in prevailing wind direction is created by decuple height of wind barrier. First $120 \mathrm{~m}$ is protected by wind barrier of average height of $12 \mathrm{~m}$. Because there is a forest land the in area of interest, so $180 \mathrm{~m}$ been determined as their protected area. For barrier that does not protect the surface has not been counted watercourses, amelioration channels, any forest vegetation, road ditches, but also diluted line vegetation. As barriers with protective functions been considered barriers with length at least $150 \mathrm{~m}$ and forest land that have been situated downwind in front of modeled area and had influence on soil loss.

\section{$\mathrm{V}$ - Factor}

Vegetable factor efficiency is in Wind Erosion Equation determined as amount of variety and orientation of vegetation cover on the soil surface. Vegetable factor is determined by amount of vegetable cover and crop residue in $\mathrm{kg} \mathrm{ha}^{-1}$. To calculate vegetative factor, equation by Lyles and Allison (1980) has been used:

$$
\mathrm{V}=\mathrm{SG}_{\mathrm{e}}=\mathrm{a} \times \mathrm{X}^{\mathrm{b}}
$$

where: $\quad \mathrm{V}$ - Vegetative factor,

$\mathrm{SG}_{\mathrm{e}}$ - Flat small-grain equivalent $\left(\mathrm{kg}_{\mathrm{g}} \mathrm{ha}^{-1}\right)$,

$\mathrm{X}-$ Amount of biomass (kg.ha-1 dry residue),

$\mathrm{a}, \mathrm{b}$ - Characteristic constants for particular crop.

In the environment of Arc GIS 10.0, program maps of individual factors have been created and they were recalculated in raster calculator. WEQ calculation by Schwab et al. (1993) has been used to calculate resulting soil loss.

$$
\mathrm{E}=0,0015 \times 2,718^{\left(-\frac{\mathrm{V}}{4500}\right)} \times\left(\mathrm{I}^{1,87} \times \mathrm{K}^{2} \times\left(\frac{\mathrm{c}}{100}\right)^{1,3}\right) \times \mathrm{L}^{0,3}
$$

\section{Results}

Taking into account wind speed determination by wind barriers and aerodynamic roughness and also unprotected field length bounded by stabile areas has resulted in wind erosion. Increasing soil loss has been in considering of unprotected land growing in the area of interest. Maximum soil loss 
calculated in the area was $99.81 \mathrm{tha}^{-1}$ year $^{-1}$. Table 1 gives area of arable land according to selected span of soil loss. Fig. 1 shows results for area of interest graphically.

Determinate the extent of erosion endangerment of particular plots principle of acceptable soil loss has been use. It is defined as maximum value of soil loss that allows sustainable and economically affordable to maintain fertility of soil. Fundament of soil erosion protection is to lower the intensity of erosion or equal to acceptable soil loss. Relative share of values calculated (Equation 3) and acceptable (tolerated) erosion determines erosion endangerment of soil and it is called erosion endangerment index. If the index is lower or equal to 1, no erosion control measures are necessary. If it is higher than 1 control measures are demanded.

$\mathrm{T} \mathrm{a} \mathrm{b} \mathrm{l} \mathrm{e} \mathrm{1.} \mathrm{Soil} \mathrm{loss} \mathrm{categories} \mathrm{and} \mathrm{soil} \mathrm{endangerment} \mathrm{area.}$

\begin{tabular}{|l|c|c|c|c|c|c|}
\hline Soil loss categories $\left(\mathrm{t} \mathrm{ha}^{-1}\right.$ year $\left.^{-1}\right)$ & $0-5$ & $5-10$ & $10-15$ & $15-40$ & $40-99.81$ & Total arable land (ha) \\
\hline Soil endangerment area (ha) & 449.81 & 266.65 & 369.79 & 1472.08 & 1220.52 & 3778.85 \\
\hline
\end{tabular}

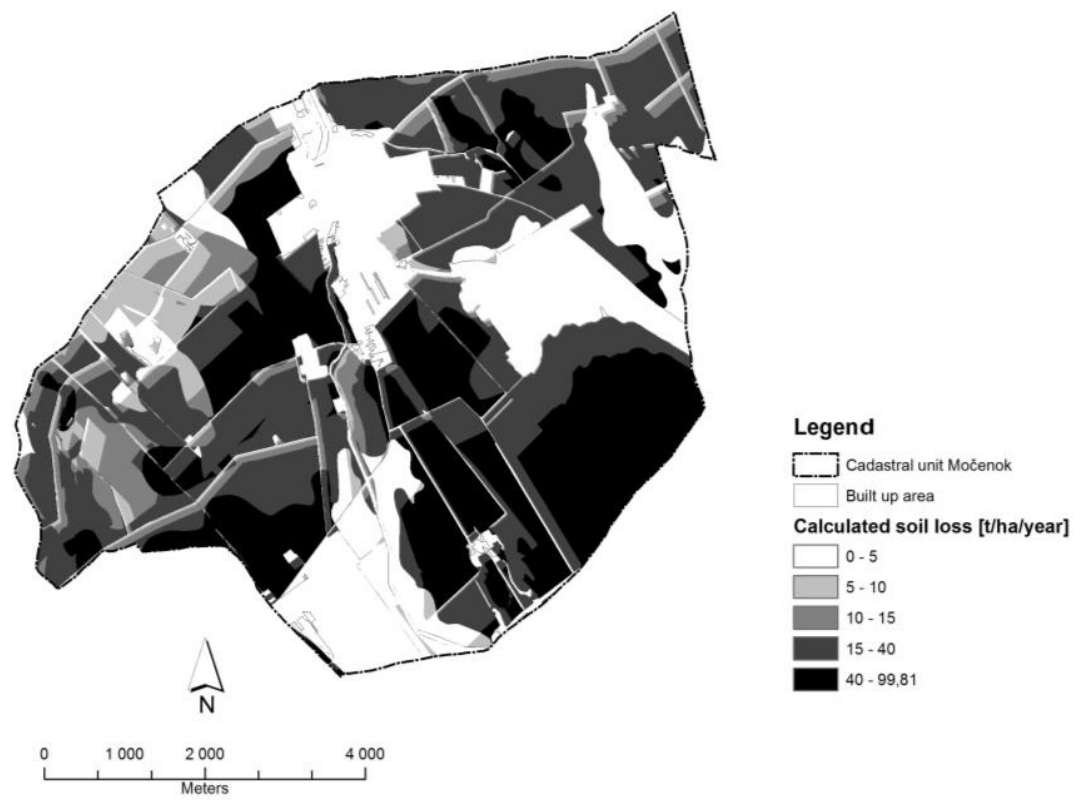

Fig. 1. Calculated soil loss according to WEQ.

Erosion endangerment index has been classified into level of soil erosion endangerment (LSEE). Changes in acceptable soil loss by wind from 40 to $15 \mathrm{t}^{-1} \mathrm{y}^{-1}$ year $^{-1}$ (according to Decree of the Ministry of Agriculture and Rural Development No. 59/2013) changes also area of soil belonging into class of level of soil endangerment of soil. Determined results for arable land in cadastral area Močenok are in Table 2.

In 1st class of LSEE (undaunted to slightly compromised soil) arable soil area been decreased by 1479.45 ha. In 2nd class of LSEE (medium threatened) were area decreased again by 103.58 ha but 
$\mathrm{T} \mathrm{a} \mathrm{b} l$ e 2. Classes of level of soil endangerment of soil for arable land in cadastral area Močenok according to acceptable values.

\begin{tabular}{|c|c|c|c|c|c|c|c|}
\hline \multirow{4}{*}{$\begin{array}{l}\text { Acceptable } \\
\text { values }\end{array}$} & \multicolumn{6}{|c|}{ Area of arable land in classes LSE } & \multirow{4}{*}{$\begin{array}{c}\text { Total arable } \\
\text { land (ha) }\end{array}$} \\
\hline & \multirow{2}{*}{\multicolumn{2}{|c|}{$\begin{array}{c}1 \\
\begin{array}{c}\text { Undaunted to slightly } \\
\text { compromised }\end{array}\end{array}$}} & \multirow{2}{*}{\multicolumn{2}{|c|}{$\frac{2}{\text { Medium threatened }}$}} & \multirow{2}{*}{\multicolumn{2}{|c|}{$\begin{array}{l}3 \\
\text { cantly compro- } \\
\text { mised }\end{array}$}} & \\
\hline & & & & & & & \\
\hline & ha & $\%$ & ha & $\%$ & ha & $\%$ & \\
\hline $40 \mathrm{t} \mathrm{ha}^{-1}$ year $^{-1}$ & 2576.88 & 68.19 & 1146.12 & 30.33 & 55.85 & 1.48 & 3778.85 \\
\hline $15 \mathrm{tha}^{-1}$ year $^{-1}$ & 1097.43 & 29.04 & 1042.54 & 27.59 & 1638.88 & 43.37 & 3778.85 \\
\hline
\end{tabular}
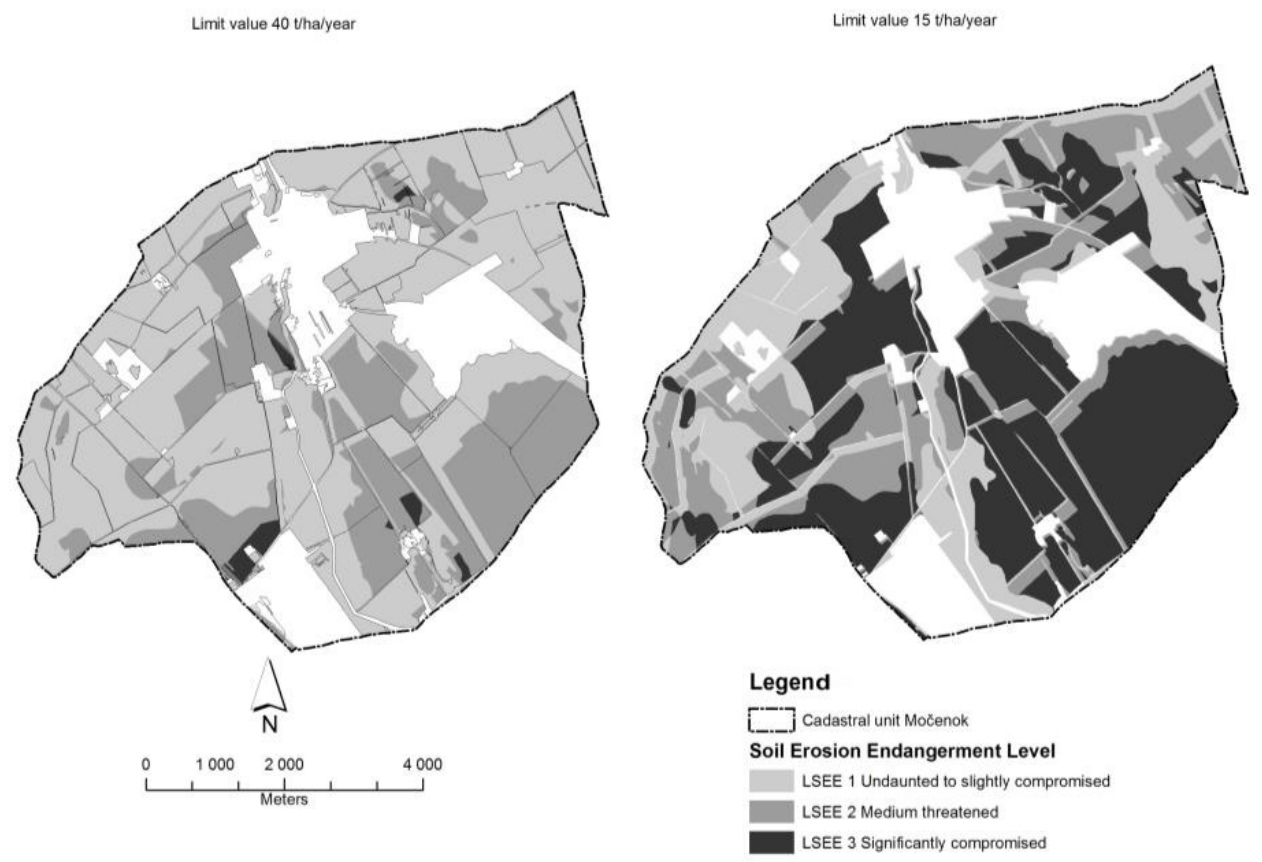

Fig. 2. Spatial comparison of Levels of Soil Endangerment in changes of acceptable values of soil loss.

in 3rd class of LSEE (significantly compromised) area increased by 1583.03 ha. Spatial comparison of levels of soil endangerment in changes of acceptable values of soil loss is showed in Fig. 2.

\section{Conclusion}

Legislative change in Slovak republic that lowers the acceptable value of soil loss by wind from 40 to $15 \mathrm{t} \mathrm{ha}^{-1}$ year $^{-1}$ has increased area in 3rd LSEE significantly. While 1st class LSEE area has been reduced by $39.15 \%$ and in 2 nd class LSEE by $2.73 \%$, in 3rd class LSEE has remarkably raise by $41.89 \%$. From obtained results we can tell that agriculture needs to protect larger areas of arable land against wind erosion. For more sustainable fertility of the soil are these changes welcome. Soil protection can be secured by changes in crop structure, i.e. cultivation of crop that relatively protect soil surface, 
agro technical erosion control measures and on critical plots also technical control measures. Using modern computing technologies we are able to model erosion control measures and determine their effect before realization.

\section{Acknowledgements}

This work was financially supported by VEGA 1/0050/12 Determination of wind erosion intensity with using of mathematical modeling.

\section{References}

Act No. 220/2004 on Protection and Use of Agricultural Land in the Slovak Republic.

Antal, J. et al. (2000). Hydromeliorácie. Protierózna ochrana polnohospodárskej pôdy. Základné ustanovenia - STN 754501. Bratislava: SÚTN.

Bielek, P. (2008). Agricultural land in Slovakia and prospects of their use (in Slovak). Bratislava: VÚPaOP.

Bujnovský, R. (2007). Society-wide aspects of agricultural soils (in Slovak). Bratislava: VÚPaOP.

Decree of the Ministry of Agriculture and Rural Development of the Slovak Republic No. 59/2013 amending and supplementing decree No. 508/2004 that execute Act No. 220/2004 on Protection and Use of Agricultural Land in the Slovak Republic.

Fryrear, D.W., Sutherland, P.L., Davis, G., Hardee, G. \& Dollar M. (2001). Wind erosion estimates with RWEQ and WEQ. In D.E. Stott, R.H. Mohtar \& G.C. Steinhardt (Eds.), Sustaining the global farm (pp. 760-765). $10^{\text {th }}$ International Soil Conservation Organization Meeting. Purdue University and the USDA-ARS National Soil Erosion Research Laboratory.

Grešová, L. \& Stredanský J. (2011). Wind erosion in the country: current trends, methods and ways of calculation (in Slovak). Nitra: SPU.

Janeček, M. et al. (2005): Protection of agricultural land against erosion (in Czech). Praha: ISV nakladatelství.

Kobza, J., Barančíková, G., Dodok, R., Hrivňáková, K., Makovníková, J., Mališ, J., Pálka, B., Styk, J. \& Širáň M. (2010). Soil monitoring in Slovakia (in Slovak). Bratislava: VÚPaOP.

Lyles, L. \& Allison B.E. (1980). Range grasses and their small grain equivalents for wind erosion control. J. Range Manag., 33(2), 143-146.

Miklós, L. et al. (2002). Landscape Atlas of the Slovak Republic (in Slovak). Bratislava: MŽP SR, Banská Bystrica: SAŽP.

Pasák, V. (1970). Wind erosion on soils (in Czech). Praha: VÚM.

Pasák, V. et al. (1984). Soil erosion protection (in Czech). Praha: SZN.

Schwab, G., Fangmeier, D.D., Elliot, W.J. et al. (1993). Soil and water conservation engineering. Wind erosion and control practices. New York: John Wiley \& Sons.

Stredanský, J. (1993). The scientific foundations of eliminating the effects of wind erosion (in Slovak). Doktorská dizertačná práca. Nitra: VŠP.

Stredanský, J. (1999). Reduction of wind erosion intensity by vegetation cover. Ekológia (Bratislava), 18(1), 96-99.

Stredanský, J. \& Stredanská A. (2001). Wind erosion intensity assessment in south - west Slovakia. Zeszyty Naukowe Akademii Rolnicznej im. H. Kollataja w Krakowie, 253-259.

Stredanský, J., Pariláková, K. \& Stred’anská A. (2006). Wind erosion in the region of Záhorie on an example of cadastral district Dojč. Ekológia (Bratislava), 25(Suppl. 1), 221-228.

Stredanský, J. \& Lackóová L. (2012). Soil wind erosion (in Slovak). Nitra: SPU.

Špánik, F., Šiška, B. et al. (2004). Biometeorology (in Slovak). Nitra: SPU.

Švehlík, R. (1989). Measuring the intensity of wind erosion with a deflameter (in Czech). Československá akadémia vied, Brno, 26(3), 35-48.

Urban, T. (2012). Determining the intensity of wind erosion using mathematical models - WEQ equation adapted to the conditions of Slovakia (in Slovak). Dizertačná práca. Nitra: SPU.

Varga, V. \& Stredanský J. (2013). Theoretical comparison of WEQ and RWEQ model to determinate soil erosion by wind (in Slovak). In ENVIRO 2013 (pp. 188-194). Nitra: SPU.

Vilček, J. (2007). Resources, potentials and assumptions used SR agricultural land (in Slovak). Enviromagazín, 6, $22-23$.

Vrána, K. (1977). Determining the intensity of wind erosion in terms (in Czech). Doktorská dizertačná práca. Praha: ČVUT.

Woodruff, N.P. \& Siddoway F.H. (1965). A wind erosion equation. Soil Science Society of America, Proceedings, 29, $602-608$. DOI: $10.2136 /$ sssaj1965.03615995002900050035x. 